\title{
Immunopathological study of Egyptian Patients with Chronic HCV Infection, Role of $\alpha$-defensin, RANTES, and TNF- $\alpha$
}

\author{
Gamal Othman*, Ayman Elbaz*, Khaled Farid ** \\ Ashraf Omar***Mohamed Arafa****
}

Departments of Medical Biochemistry*, Tropical Medicine**, Internal Medicine $* * *$ Pathology****, Mansoura Faculty of Medicine

\begin{abstract}
Background: Hepatitis $C$ virus infection and its associated liver inflammatory disease is a major global health problem affecting over 170 million people worldwide. Following viral infection, multiple pro-inflammatory mediators contribute to recruitment of immune cells to the liver and to the generation of an anti-viral immune response. Multiple recent publications mark chemokines and their receptors as key players in leukocyte recirculation through the inflamed liver. Furthermore, chemokines may also be involved in liver regeneration, fibrosis, and in malignant transformation, which is induced by the persistence of inflammation. The Aim of this Study: The present study aimed to measure serum TNF- $\alpha, R A N T E S$ and $\alpha$-defensins levels in patients with chronic hepatitis $C$ and to estimate their relation to $H C V$ viremia as well as grade of liver inflammation and stage of fibrosis. Materials and Methods: 40 patients with chronic HCV and 20 normal controls were tested for liver function tests (Albumin, ALT, AST, ALP, Bilirubin), prothrombin activity, FBS, creatinine, $C B C, A F P, H C V$ RNA, RANTES, TNF- $\alpha$ and $\alpha$-defensins. Results: There were significant increase of serum levels of $\alpha$-Defensins, RANTES and TNF- $\alpha$ in patients with chronic $H C V$ infection compared with control group $(P<0.05)$. $\alpha-$ defensins and RANTES showed significant positive correlation with HCV RNA viral load, grade of activity and stage of fibrosis while TNF- $\alpha$ showed significant positive correlation with grade of activity and stage of fibrosis only. Conclusion: The high linear correlation of levels of $\alpha$-Defensins, RANTES and TNF- $\alpha$ with stage of liver fibrosis and grade of activity makes the measurement of these peptides reliable markers to evaluate liver fibrosis stage. The effects of these peptides need further studies and researches on a wide scale to clarify their possible mechanisms.
\end{abstract}

\section{INTRODUCTION}

$\mathrm{HCV}$ is a major human pathogen, infecting more than 170 million individuals; approximately $70 \%$ of those infected become chronic carriers and are at severe risk of developing liver fibrosis and cirrhosis ${ }^{(1)}$.

Production of chemokines in the liver is likely to play a role in $\mathrm{HCV}$ infection, as infiltration of lymphocytes has been observed in concomitance with chronic disease ${ }^{(2)}$. RANTES (regulated upon activation, 
normal $\mathrm{T}$ cell expressed and secreted) is a member of the chemokine family of chemotactic properties for $\mathrm{T}$ lymphocytes, monocytes, induced by some viruses and stimulates the host immune response to viral infections ${ }^{(3) \text {. }}$ Inflammatory cytokines, including tumor necrosis factor-alpha (TNF- $\alpha$ ), are integral part of inflammation in chronic hepatitis $\mathrm{C}$ infection. TNF- $\alpha$ and both types of circulating soluble TNF receptors (sTNFR) were not only increased in $\mathrm{HCV}$-infected patients compared with controls, but sTNFR showed significant correlation with aminotransferase activities \& the histological severity of inflammation $^{(4)}$.

Defensins are important components of the innate immunity, next to the complement pathway and phagocytes, are antimicrobial peptides, which play a pivotal role as key effectors of the immune system and act as endogenous antibiotics (5). Mammalian defensins are classified into three distinct sub-families due to the disulfide array: $\alpha-, \beta$ - und $\theta$ defensins that exhibit a direct antimicrobial activity against a broad spectrum of microorganisms includes viruses ${ }^{(6) .}$

The present study aimed to measure serum levels of $\alpha$-Defensins, RANTES and TNF- $\alpha$ in patients with chronic hepatitis $\mathrm{C}$ and estimate their relation to $\mathrm{HCV}$ viremia as well as grade of liver inflammation and stage of fibrosis.

\section{SUBJECTS \& METHODS}

Forty Egyptian patients with chronic hepatitis $\mathrm{C}$ virus (HCV) infection were recruited on their first examination at the Tropical Disease Unit Outpatient Clinic, Mansoura University Hospital. Twenty uninfected healthy subjects, matched for sex, and age, were recruited as a control group. All patients underwent a complete medical and laboratory evaluation including a liver ultrasound scan and biopsy.

The diagnosis of $\mathrm{HCV}$ infection was defined by typical biochemical and histological data and by detection of anti-HCV antibodies (Abbot Axsym HCV-3 and Ortho HCV 3.0 ELISA). Serum HCV-RNA was determined by real time PCR using Cobas Ampliprep/Cobas TaqMan, Roche Diagnostics, Pleasanton, USA, with detection limits $>600$ HCV-RNA $\mathrm{IU} / \mathrm{ml}$.

The entire study population was negative for other forms of viral hepatitis and for human immunodeficiency virus infection (HIV). Other conditions known to cause liver dysfunction were excluded on the basis of clinical evaluation and liver biopsy. The patients involved in this study stopped taking steatogenic or antiviral drugs 6 months ago. None showed clinical or biochemical signs of advanced liver disease (their plasma prothrombin time and serum albumin were within normal ranges).

Blood samples were withdrawn from all subjects of the present study and each sample was divided into 3 aliquots; the first aliquot as EDTA anticoagulated blood for $\mathrm{CBC}$, the second one as citrated plasma for measuring prothrombin activity and the third one was allowed to clot, centrifuged at $7000 \mathrm{rpm}$ for 10 minutes to obtain serum which was 
divided into two parts; the first part was used for measurement of liver function tests (Albumin, ALT, AST, ALP and Bilirubin), , fasting blood glucose (FBG), creatinine and $\alpha$ fetoprotein and the second part was stored at $-70^{\circ} \mathrm{C}$ until assayed for $\alpha$ defensins, RANTES and TNF- $\alpha$.

RANTES and TNF- $\alpha$ were measured by sandwich ELISA technique using RANTES, TNF- $\alpha$ antigens ELISA kits purchased from Raytech ELISA kits (Helena laboratories, Beaumont, Texas).

$\alpha$ - defensins were measured by sandwich ELISA technique using $\alpha$ defensins antigens ELISA kits purchased from Hycult ELISA kits (Helena laboratories, Beaumont, Texas).

Needle liver biopsy specimens were obtained from all patients for determination of stage of liver fibrosis and measurement of activity index with an 18-gauge needle with a minimum of 5 portal tracts and were routinely stained with hematoxylineosin stain. Histological analysis was independently performed by the pathologist without knowledge of any clinical and biological data except that patients had chronic HCV.

Fibrosis were assessed according to the Metavir scoring system ${ }^{(7)}$, on a five-point scale $(\mathrm{F} 0=$ no fibrosis, $\mathrm{F} 1=$ portal fibrosis without septa, F2=few septa, F3=numerous septa without cirrhosis, and F4=cirrhosis). Activity grading by the Metavir system (based on the intensity of periportal and lobular necroinflammation) were scored as follows: $\mathrm{A} 0=$ no histological activity,
$\mathrm{A} 1=$ mild activity, $\mathrm{A} 2=$ moderate activity and $\mathrm{A} 3$ = severe activity. The presence of stage F0, F1 was termed "non significant liver fibrosis"; the presence of stage F2, F3, or F4 was termed "significant fibrosis", whereas the term "advanced fibrosis" was reserved for stage F3 or F4. The presence of stage F4 was termed "liver cirrhosis".

Statistical analysis: Statistical analysis was done by using MedCalc program version 10.0.1 ${ }^{(8)}$. Student $t$ test was used for quantitative data (mean $\pm \mathrm{SD}$ ) to compare any variable against control group. Spearman rank correlation coefficient was done to study the relation between variables. Odds ratio was done to calculate the ratio of the odds of the outcome in two groups. $\mathrm{P} \leq 0.05$ is considered significant.

\section{RESULTS}

Table (1) showed the differences between chronic HCV group and control group as regards biochemical parameters of liver function tests, $\mathrm{CBC}$, creatinine, FBG, AFP and HCV-RNA viral load for evaluation of liver function and exclusion of other diseases such as diabetes mellitus, renal impairment and hepatic malignancy. This spreadsheet showed significant increase in ALT, AST, HCV_RNA viral load and significant decrease in platelets and prothrombin concentration among chronic $\mathrm{HCV}$ group when compared with control group. 
Table (1): Biochemical parameters among chronic HCV group compared to control group (Median + range) with test of significance.

\begin{tabular}{|c|c|c|c|}
\hline Parameter & $\begin{array}{l}\text { Control } \mathbf{N}=\mathbf{2 0} \\
\text { Median(range) }\end{array}$ & $\begin{array}{l}\text { HCV N=40 } \\
\text { Median (range) }\end{array}$ & $P$ value \\
\hline Albumin (gm/dl & $4.3(4.0-4.6)$ & $4.25(3.7-4.6)$ & 0.288 \\
\hline ALT ( U/L) & $21.5(17-36)$ & $52.5(18-88.5)$ & 0.001 \\
\hline AST (U/L) & $23.5(17-37)$ & $45(12-91)$ & 0.003 \\
\hline Bilirubin (mg/l) & $0.75(0.5-1.14)$ & $0.89(0.5-2.1)$ & 0.121 \\
\hline Prothrombin Conc. (\%) & $96(87-100)$ & $84(73-95)$ & 0.001 \\
\hline AFP (ng/dl) & $3.32(0.9-6.3)$ & $3.79(0.9-17.6)$ & 0.240 \\
\hline Creatinine (mg/dl) & $0.8(0.6-1.3)$ & $0.9(0.6-1.3)$ & 0.313 \\
\hline FBG (mg/dl) & $93(76-126)$ & $95(76-140)$ & 0.473 \\
\hline Hb (gm/dl) & $13.8(12.5-16)$ & $13.4(11.7-16.6)$ & 0.777 \\
\hline PLT $\left(10^{3}\right.$ cells $\left./ \mathrm{L}\right)$ & $245(160-330)$ & $168(107-296)$ & 0.008 \\
\hline WBCs $\left(10^{3}\right.$ cells $\left./ \mathrm{L}\right)$ & $6.1(3.9-8.7)$ & $5.6(3.5-13.7)$ & 0.879 \\
\hline $\mathbf{A L P}(\mathrm{U} / \mathrm{L})$ & $99.5(51-194)$ & $98(53-198)$ & 0.9653 \\
\hline HCV_RNA (IU/ml) & Below detection & $415551.5(15214-175095)$ & $\mathrm{P}<\mathbf{0 . 0 0 0 1}$ \\
\hline
\end{tabular}

The present study showed significant increase of serum levels of $\alpha$-Defensins, TNF- $\alpha$, RANTES in patients with chronic HCV infection compared with control group $(\mathrm{P}<0.05)$ as shown in table 1 .

Table (2): $\alpha$-Defensins, TNF- $\alpha$, RANTES among chronic HCV group compared to control group (Median + range) with test of significance.

\begin{tabular}{llll}
\hline Parameter & $\begin{array}{l}\text { Control } \mathbf{N}=\mathbf{2 0} \\
\text { Median (range) }\end{array}$ & $\begin{array}{l}\text { HCV N=40 } \\
\text { Median (range) }\end{array}$ & P value \\
\hline $\boldsymbol{\alpha}$-defensin $(\mathbf{p g} / \mathbf{m l})$ & $2.72(1.76-5.22)$ & $9.08(5.86-9.98)$ & 0.023 \\
\hline RANTES $(\mathbf{p g} / \mathbf{m l})$ & $21.56(8.66-41.44)$ & $77.62(27-155)$ & 0.0052 \\
\hline TNF- $\boldsymbol{\alpha}(\mathbf{p g} / \mathbf{m l})$ & $14.29(6.68-28.56)$ & $44.4850(26.75-149.50)$ & 0.012 \\
\hline$P \leq 0.05$ is considered significant. & &
\end{tabular}




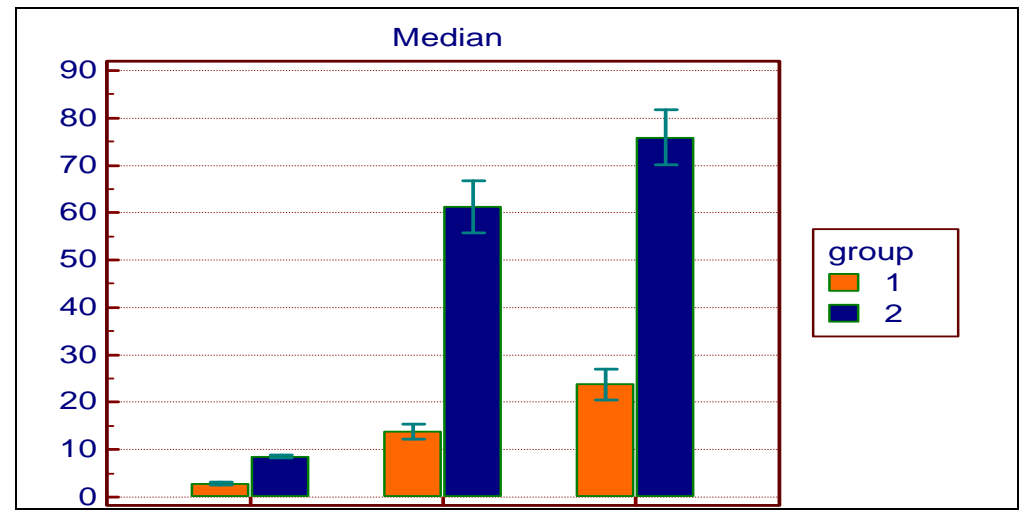

Figure (1): Medians of serum levels of $\alpha$-defensin, RANTES, and TNF- $\alpha$ in HCV patients compared with control group

There were significant positive correlation between $\alpha$-Defensins and RANTES with HCV RNA viral load, grade of activity and stage of fibrosis while TNF- $\alpha$ showed significant positive correlation with grade of activity and stage of fibrosis only as shown in table (2) and this is supported by description of the relationship between two variables and to predict one variable from another by using linear regression between different measured parameters as shown in figure (2).

Table (3): Spearman correlation coefficient between biochemical parameters among HCV cases and HCV RNA viral load, grade of activity and stage of fibrosis

\begin{tabular}{lccc}
\hline Parameter & HCV RNA viral load & Activity grade & Stage of fibrosis \\
\hline $\boldsymbol{\alpha}$ defensin (pg/ml) & $\mathrm{r}=0.425$ & $\mathrm{r}=0.341$ & $\mathrm{r}=0.430$ \\
& $\mathrm{p}=0.017$ & $\mathrm{p}=0.035$ & $\mathrm{p}=0.015$ \\
\hline RANTES (pg/ml) & $\mathrm{r}=0.442$ & $\mathrm{r}=0.507$ & $\mathrm{r}=0.591$ \\
& $\mathrm{p}=0.010$ & $\mathrm{p}=0.001$ & $\mathrm{p}=0.0001$ \\
\hline TNF- $\boldsymbol{\alpha}(\mathbf{p g} / \mathbf{m l})$ & $\mathrm{r}=0.0648$ & $\mathrm{r}=0.612$ & $\mathrm{r}=0.612$ \\
& $\mathrm{P}=0.6911$ & $\mathrm{P}<0.0001$ & $\mathrm{P}<0.0001$ \\
\hline
\end{tabular}

$P \leq 0.05$ is considered significant. 

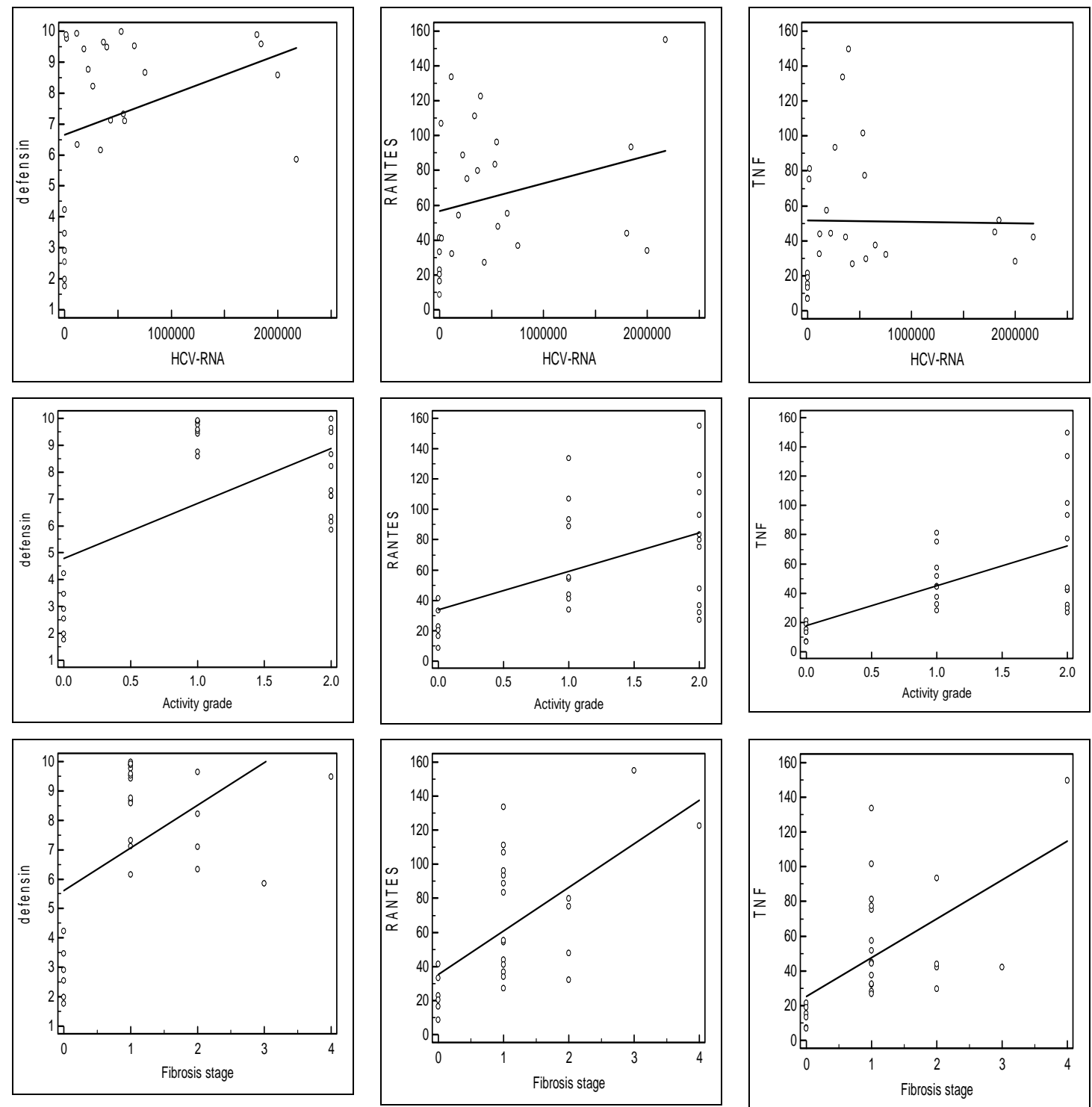

Figure (2): scatter diagram and linear regression between each of $\alpha$-defensin, RANTES, TNF- $\alpha$ with HCV RNA viral load, grade of activity and stage of fibrosis. 


\section{DISCUSSION}

During $\mathrm{HCV}$ infection, chronic inflammation, regeneration and fibrosis are the key elements leading to liver dysfunction. Cytokines and chemokines are major regulators of these processes. Therefore, the outcome of HCV infection depends in part on a complex network of cytokine and chemokine interactions that orchestrate the innate and adaptive immune responses to $\mathrm{HCV}$ infection $^{(9)}$.

There were significant increase of serum levels of $\alpha$-Defensins, RANTES and TNF- $\alpha$ in patients with chronic HCV infection compared with control group ( $\mathrm{P}<0.05)$. Also, $\alpha-$ Defensins and RANTES showed significant positive correlation with HCV RNA viral load, grade of activity and stage of fibrosis while TNF- $\alpha$ showed significant positive correlation with grade of activity and stage of fibrosis only.

These results were similar to the single previous research done by Aceti et al. ${ }^{(10)}$ who reported that $\mathrm{HCV}$ induces $\alpha$-defensins expression. These results could be explained by its participation to tissue healing processes, as they have been reported to elicit fibroblast proliferation and deposition of extracellular matrix. Therefore, it is possible that, at physiologic concentrations, $\alpha$ defensins might promote tissue repair, while at higher, pathologic concentrations, they might increase fibrogenesis and enhance a degenerative process in which functional hepatic tissue is replaced by fibrotic nonfunctional tissue.
Depending upon the concept of low number of researches on $\alpha$ defensins in $\mathrm{HCV}$, the results of the present study could support other comparative researches. During Chronic Periodontitis associated with HIV-1 infection, there is an increase in defensins, that known to have potent anti-HIV-1 activity (11). In human peripheral blood, following the induction of lipopolysaccharide or heat-inactivated bacterial cells; $\alpha$ defensins 1-3 genes were constitutively transcribed indicating their antimicrobial role ${ }^{(12) .}$

The findings of Chaly et al. ${ }^{(13),}$ suggested that neutrophil defensins have the potential to modulate the inflammatory responses through regulation of cytokine production and adhesion molecule expression.

Experimental evidence suggests that immune response factors, especially the pro-inflammatory cytokines, play an important role in liver injury induced by $\mathrm{HBV}$ and $\mathrm{HCV}^{(14)}$

The results of Pawlak et al. (15), suggested that the presence of viral hepatitis status and liver injury are novel determinants of increased oxidative stress, as well as of increased RANTES levels in uremic patients. Another study demonstrated that hepatitis $\mathrm{C}$ virus is capable of RANTES gene expression in both nonhepatic and hepatic cell lines ${ }^{(\mathbf{1 6}) .}$

On contrary to the present study, Ruggieri1 et al. ${ }^{(17)}$, reported that HCV core protein has opposite effects on the expression of RANTES in different cell types in vitro, possibly reflecting a similar scenario in different microenvironments in vivo. 
This result is analogous to Egyptian study done by Helaly and Abou Shamaa ${ }^{(18)}$, who stated that TNF- $\alpha$ levels were dramatically elevated in HCV infected patients, in spite of their normal serum aminotransferases' activities as compared with healthy control subjects. Although, serum levels of TNF- $\alpha$ were slightly elevated in viremic than non-viremic $\mathrm{HCV}$ infected patients, yet this difference did not reach the statistically significant level.

Increased concentrations and activity of plasma cytokines produced by monocytes, macrophages, and hepatocytes in patients with alcoholic liver diseases, correlate with the clinical course of liver diseases and are of prognostic value. Especially, high levels of circulating tumor necrosis factor (TNF- $\alpha$ ) that have been found to correlate with increased mortality in alcoholic hepatitis. Moreover, hepatic RANTES was increased in patients with alcoholic hepatitis ${ }^{(19) .}$

It was proved that RANTES was transcriptionally induced in human hepatoma cells by treatment with TNF- $\alpha$ via activation of NF-kappa B and p38 MAP kinase, presumably suggesting that TNF- $\alpha$ induced expression of RANTES plays an important role in cell-mediated liver injury in alcoholic liver diseases ${ }^{(\mathbf{2 0}) .}$

In addition, cytokines such as TNF- $\alpha$ were upregulated following infection. Furthermore, the vigorous immune response generated against $\mathrm{HCV}$ was associated with a dramatic change in the pattern of chemokine and chemokine receptor mRNA levels detected in the liver. The expression patterns of more than 16 chemokines and chemokine receptors were significantly attenuated during acute and chronic human HCV infection (21).

Both in patients with chronic $\mathrm{HCV}$ infection and in experimental models, TNF- $\alpha$ level in plasma, serum, and peripheral blood mononuclear cells are increased. Activation of the TNF- $\alpha$ system plays a central role in killing mechanisms of hepatitis C virus-specific human cytotoxic $\mathrm{T}$ cells ${ }^{(22) \text {. }}$

Activation of TNF- $\alpha$ system has a pivotal role in the inflammatory process of chronic hepatitis $\mathrm{C}$, and TNF- $\alpha$ levels correlate with the degree of inflammation ${ }^{(23) \text {. }}$

It is not surprising that a number of cytokines have been involved in the outcome of HCV infection. In particular, the persistence of the virus and the response to antiviral therapy have been suggested to be associated with the production of inappropriate levels of TNF- $\alpha^{(24) .}$

The $\alpha$-defensins human neutrophil peptides (HNPs) have been reported to increase the production of TNF- $\alpha$. Increased levels of proinflammatory factors (e.g. IL-1, TNF- $\alpha$ ) at the site of microbial infection are likely to amplify local inflammatory responses. This might be further reinforced by the capacity of some human $\alpha$-defensins to inhibit the production of immunosuppressive glucocorticoids by competing for the binding of adrenocorticotropic hormone to its receptor. Moreover, human $\alpha$-defensins can enhance or suppress the activation of the classical pathway of complement in vitro by binding to solid-phase or fluid-phase complement $\mathrm{C} 1 \mathrm{q}$, respectively ${ }^{(25)}$. 
Conclusion: The high linear correlation of alpha-defensin levels, RANTES and TNF- $\alpha$ with stage of liver fibrosis and grade of activity makes the measurement of these peptides reliable markers to evaluate liver fibrosis stage. The effects of these peptides need further studies and researches on a wide scale to clarify their possible mechanisms.

\section{REFERENCES}

1. Gangadharan B, Antrobus R, Dwek R, and Zitzmann N. (2007): Novel serum biomarker candidates for liver fibrosis in hepatitis $\mathrm{C}$ patients. Clinical Chemistry 53(10):1792-1799.

2. Soo H M, Garzino-Demo A, Hong W (2002): Expression of a full-length hepatitis $\mathrm{C}$ virus cDNA up-regulates the expression of CC chemokines MCP-1 and RANTES. Virology 303:253-277.

3. Crispe IN, Dao T, Klugewitz K, Mehal WZ, and Metz DP. (2000): The liver as a site of Tcell apoptosis: Graveyard, or killing field. Immunol. Rev., 174: 47-62.

4. Itoh Y, Okanoue $\mathbf{T}$, Ohnishi $\mathbf{N}$ (1999): Serum levels of soluble tumor necrosis factor receptors and effects of interferon therapy in patients with chronic hepatitis c virus infection. Am. J. Gastroenterol., 94:1332-1340.

5. Ganz T. (2003): Defensins: antimicrobial peptides of innate immunity. Nature Reviews Immunology 3(9):710-720.

6. Yang D, Biragyn A, Kwak LW, Oppenheim JJ (2002):
Mammalian defensins in immunity: more than just microbicidal. Trends in Immunology 23(6):291-296.

7. Poynard T, Bedossa P, Opolon P. (1997): Natural history of liver fibrosis progression in patients with chronic hepatitis $\mathrm{C}$. The OBSVIRC, METAVIR, CLINIVIR, and DOSVIRC groups. Lancet 349 (9055): 825832.

8. Schoonjans F, Zalata A, Depyudt CE, and Comhaire FH (1995): MedCalc: a new computer program for medical statistics. Computer Methods and Programs in Biomedicine 48: 257-262.

9. Heydtmann M, Lalor PF, Eksteen JA, Hubscher SG, Briskin M, Adams DH. (2005): CXC chemokine ligand 16 promotes integrin-mediated adhesion of liver-infiltrating lymphocytes to cholangiocytes and hepatocytes within the inflamed human liver. J. Immunol., 174:1055-1062.

10. Aceti A, Mangoni ML, Pasquazzi C, Fiocco D, Marangi M, Miele R, Zechini B, Borro M, Versace I, Simmaco M. (2006): Alpha-defensin increase in peripheral blood mononuclear cells from patients with hepatitis $\mathrm{C}$ virus chronic infection. J. Viral Hepat., 13(12):821-827

11. Jotwani R, Muthukuru M, Cutler CW (2004): Increase in HIV receptors/co-receptors/ $\boldsymbol{\alpha}$ defensins in inflamed human gingiva. J Dent Res., 83(5):371377 
12. Fang $X M$, Shu $Q$, Chen $Q X$, Book M, Sahl HG, Hoeft A, Stuber F (2003): Differential expression of alpha- and betadefensins in human peripheral blood. Eur. J. Clin. Invest., 33(1):82-87

13. Chaly YV, Paleolog EM, Kolesnikova TS, Tikhonov II, Petratchenko EV, Voitenok NN (2000): Neutrophil alphadefensin human neutrophil peptide modulates cytokine production in human monocytes and adhesion molecule expression in endothelial cells. Eur. Cytokine Netw., 11(2):257-266

14. Petruzzi M, De Benedittis $M$, Loria MP, Dambra P, D'Oronzio L, Capuzzimati C, Tursi A, Lo Muzio L, Serpico R. (2004): Immune response in patients with oral lichen planus and $\mathrm{HCV}$ infection. Int. J. Immunopathol. Pharmacol., 17:93-98.

15. Pawlak K, Pawlak D and Mysliwie M (2004): Hepatitis intensified oxidative stress, MIP$1 \beta$ and RANTES plasma levels in uremic patients. Cytokine 28(6): 197-204

16. Crispe N, Dao T, Klugewitz K, Mehal Z, and Metz P. (2000): The liver as a site of T-cell apoptosis: Graveyard, or killing field? Immunol. Rev., 174: 47-62.

17. Ruggieri1 A, Franco1 M, Gatto I, Kumar $A$ and Rapicetta $M$ (2007): Modulation of RANTES expression by $\mathrm{HCV}$ core protein in liver derived cell lines. BMC Gastroenterology 7:21

18. Helaly GF and Abou Shamaa LA (2006): Tumor Necrosis
Factor-Alpha in Hepatitis C Virus Infection: A Correlation with Viral Activity and Serum Aminotransferases. The Egyptian journal of immunology 13(1):2738.

19. Hirano F, Kobayashi A, Makino I. (2003): Inhibition of TNF- $\alpha$-induced RANTES expression in human hepatocytederived cells by fibrates, the hypolipidemic drugs. Int. Immunopharmacol., 3(2):225-32

20. Hirano F, Komura K, Fukawa E, Makino I. (2003): Tumor necrosis factor- $\alpha$ (TNF- $\alpha$ )induced RANTES chemokine expression via activation of NFkappaB and p38 MAP kinase: roles of TNF-alpha in alcoholic liver diseases. J. Hepatol., 38(4):483-489

21. Asselah T, Bieche I, Laurendeau I, Paradis V, Vidaud D, Degott C, et al. (2005): Liver gene expression signature of mild fibrosis in patients with chronic hepatitis $\mathrm{C}$. Gastroenterology 129:2064-2075.

22. Lio D, Caruso C, Di Stefano R, Colonna RG, Ferraro D, Scola L, Crivello A, Licata A, Valenza LM, Candore G, Craxi A, Almasio PL. (2003): IL-10 and TNF- $\alpha$ polymorphisms and the recovery from $\mathrm{HCV}$ infection. Human Immunology 64:674 680

23. Knobler $H$ and Schattner $A$ (2005): TNF- $\alpha$, chronic hepatitis $\mathrm{C}$ and diabetes: a novel triad. Q. J. Med., 98:1-6

24. Yee LJ, Tang J, Herrera J, Kaslow RA and van Leeuwen DJ (2000): Tumor necrosis factor 
gene polymorphisms in patients with cirrhosis from chronic hepatitis $\mathrm{C}$ virus infection. Genes Immunity 1: 386.

25. Craddock RM, Huang JT, Jackson E, et al. (2008):
"Increased alpha defensins as a blood marker for schizophrenia susceptibility". Mol. Cell Proteomics 7: 1204. 


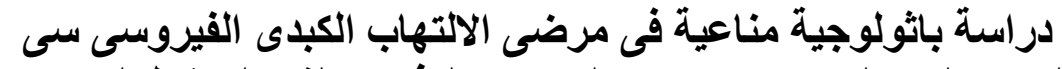

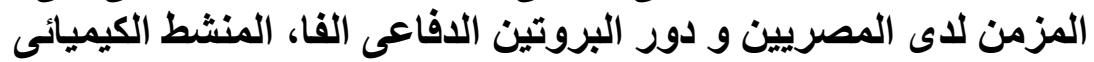 رانتيس و معامل تنحر الورم- الفاعي الفاعي}

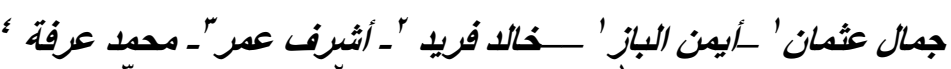

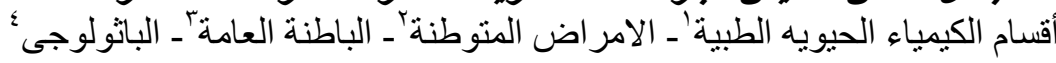
كلية الطب - جامعة المنصورة

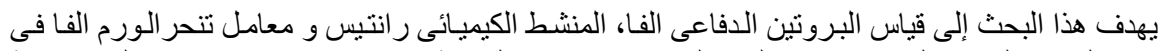

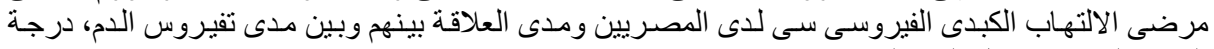
التهاب الكبد و مر احل تليف الكبد الكبد.

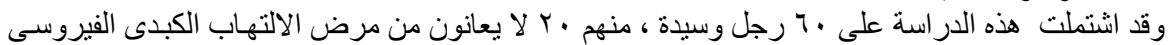

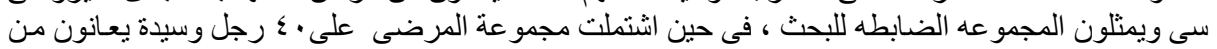

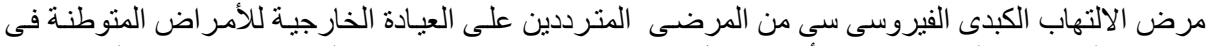

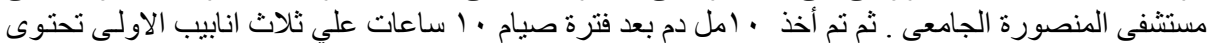

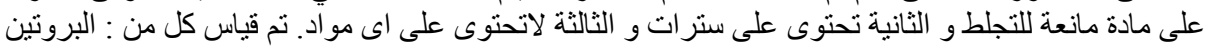

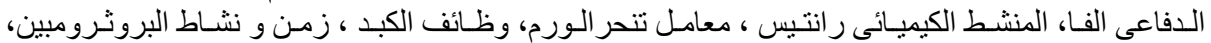

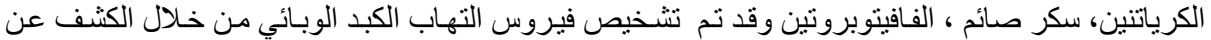

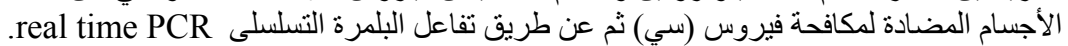

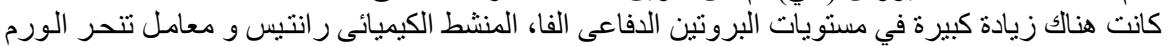

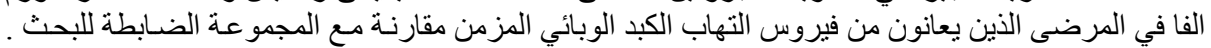

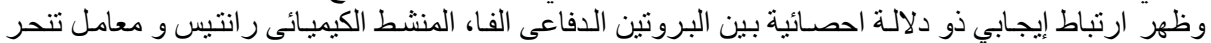

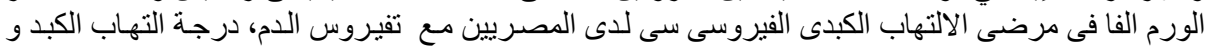

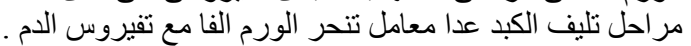

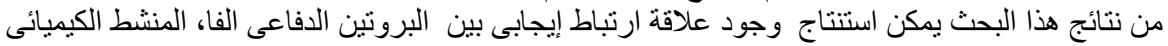

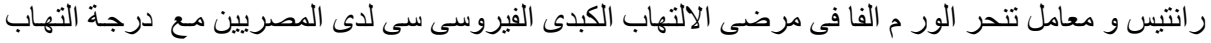

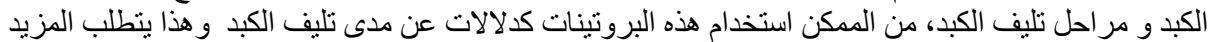
من البحث و الدر اسة لهذه البروتينات على نطاق الكن أوسع من الناس. 